\title{
前立腺摘除術における止血法の検討
}

— vesical neck closure 法について —

$\begin{array}{ccccc} & \text { 今 } & \text { 村 } & \text { 一 } & \text { 男 } \\ \text { 中 } & \text { 西 } & \text { 欽 } & \text { 也 } \\ & \text { 菅 } & & \text { 孝 } & \text { 幸 } \\ & \text { 近 } & \text { 藤 } & \text { 常 } & \text { 郎 } \\ \text { 昭和大学医学部泌尿器科学教室 } & \text { 落 } & \text { 合 } & \text { 元 } & \text { 宏 } \\ \text { (主任: 赤坂 裕教授) } & \text { 吉 } & \text { 田 } & \text { 英 } & \text { 機 } \\ & \text { 中 } & \text { 野 } & \text { 博 } & \text { 行 } \\ & \text { 丸 } & \text { 山 } & \text { 邦 } & \text { 夫 } \\ & \text { 池 } & \text { 内 } & \text { 隆 } & \text { 夫 } \\ & \text { 矢 } & \text { 島 } & \text { 七 } & \text { 生 }\end{array}$

\section{CONTROL OF HEMORRHAGE IN PROSTATECTOMY STUDY OF VESICAL NECK CLOSURE}

Kazuo Imamura, Kinya Nakanishi, Takayuki Suga, Tsuneo Kondo, Motohiro Ochiai, Hideki Yoshida, Hiroyuki Nakano, Kunio Maruyama, Takao Ikeuchi and Nanao Yajima

From the Department of Urology, School of Medicine, Showa University

(Chairman: Prof. H. Akasaka, M.D.) tion.

In prostatectomy, the most important problem is how to decrease bloodloss during and after opera-

"Vesical neck closure" is the method which Lower devised for suprapublic prostatectomy first in 1927. We performed suprapublic prostatectomy with this method in 84 cases since 1967. In other words, we studied "vesical neck closure".

The bloodloss was measured by gravimetry.

1. The bloodloss:

The bloodloss was 1230 c.c. at max., 35 c.c. at min. and 378 c.c. on the average.

2. The relation between bloodloss and anesthesia:

The patients operated under S.C. were 55 cases and their average bloodloss was 414 c.c. The patients operated under Ep. were 28 cases and their average bloodloss was 284 c.c.

3. The period when macroscopic hematuria was observed:

In the cases operated by the above mathod, macroscopic hematuria continued for 8.1 days.

4. The postoperative vesical neck stricture:

The postoperative vesical neck stricture was observed in 2 cases out of 84 and both of them were cured by electroresection method by means of sectio alta.

前立腺摘除術の最大の問題は術中・術後の出血を如何

にして減少させるかといらことであるが，吾々は 1967
年より恥骨上前立腺摘除術に際し vesical neck closure

（以下 VNC と略す）を行ない，その症例が約80例に達 
したので，それ以前に吾々が行なつていた Harris 法の 変法を control として主として術中の出血を中心に検討 した．尚，術者は熟練者のみに限定することはなかつ た.

\section{手術方法}

(a) control

VNC 法を行なう以前は主として Harris 法の変法に よつて前立腺摘除術を施行していた. 即ち膀胱頝部の 4 時 と 5 時の方向の間及び 7 時 と 8 時の方向の間に夫々 catgutをかけ結紮した後， 3 時の方向より 9 時の方向迄 catgut にて前立腺床にまで深く針をかけ連続縫合する方 法である.

(b) VNC 法 (Fig. 1)

吾々は腺腫を摘除した後, 尿道にカテーテルを插入 し，そのカテーテルを中心に膀胼頝部の前後縁及び前立 腺床の前後壁を共に catgut にて縫合し, 膀胀と前立腺 休とを完全に遮断し, 前立腺床よりの出血が膀胱内に流 入しないよらにするわけである.

Fig. 1 Vesical Neck Closure(our method)

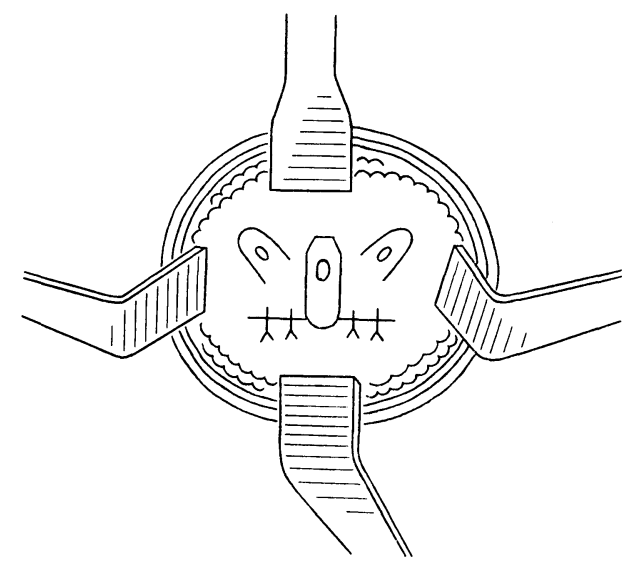

対象となつた症例

(a) 年令 (Table 1)

control の症例は50例で最年少は56才，最高令は 88 才 で平均年令69.4才である.VNC 法を行なつた症例は84 例で, 最年少は 50 才, 最高令は88才で平均年令 70.1 才で

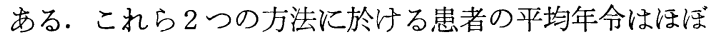
同じである.

(b) 術前腎機能検查 (Table 2)

(i) Fishberg 濃縮試験

controlでは50例中最高比重1012迄のものが47例（94.0
Table 1 Age of Patients

\begin{tabular}{c|c|c}
\hline Age (yrs) & $\begin{array}{c}\text { Control } \\
\text { No. of Cases }\end{array}$ & $\begin{array}{c}\text { Vesical Neck } \\
\text { Closure No. } \\
\text { of Cases }\end{array}$ \\
\hline $41-50$ & & 1 \\
\hline $51-60$ & 4 & 4 \\
\hline $61-70$ & 22 & 42 \\
\hline $71-80$ & 23 & 33 \\
\hline $81-$ & 1 & 4 \\
\hline Average & 69.4 & 70.1 \\
\hline
\end{tabular}

Table 2 Renal Function Test

\begin{tabular}{|c|c|c|c|c|c|}
\hline & \multicolumn{2}{|c|}{ Control } & \multicolumn{2}{|c|}{$\begin{array}{c}\text { Vesical Neck } \\
\text { Closure }\end{array}$} \\
\hline & & $\begin{array}{l}\text { No. of } \\
\text { Cases }\end{array}$ & $\%$ & $\begin{array}{l}\text { No. of } \\
\text { Cases }\end{array}$ & $\%$ \\
\hline \multirow{3}{*}{$\begin{array}{l}\text { Fishberg's } \\
\text { Concentration } \\
\text { Test }\end{array}$} & Over1018 & 35 & 70.0 & 61 & 72.6 \\
\hline & $1012-1017$ & 12 & 24.0 & 20 & 23.8 \\
\hline & under 1011 & 3 & 6.0 & 3 & 3.6 \\
\hline \multirow{2}{*}{$\begin{array}{l}\text { PSP } \\
\text { Excretory } \\
\text { Test }\end{array}$} & Over $50 \%$ & 43 & 86.0 & 74 & 88.1 \\
\hline & Under $50 \%$ & 7 & 14.0 & 10 & 11.9 \\
\hline \multirow{2}{*}{ BUN } & Under $20 \mathrm{mg} / \mathrm{dl}$ & 43 & 86.0 & 73 & 86.9 \\
\hline & Over $20 \mathrm{mg} / \mathrm{dl}$ & 7 & 14.0 & 11 & 13.1 \\
\hline
\end{tabular}

$\%), 1011$ 以下が 3 例 ( $6.0 \%$ ) で, 最低の症例では 1008 を示すものもあつた. VNC 法の症例に於いては84例中 最高比重1012迄のものが81例 (96.4\%) で， 3 例（ 3.6 \%) が1011であつた.

\section{(ii) PSP 排泄試験}

2 時間の総排泄量によつて区分してみた. controlでは50\%以上排泄したものは50例中43例（86.0 $\%), 50 \%$ 未満は 7 例 $(14.0 \%)$ で最低 $20 \%$ というものも 含まれている.VNC 法の症例に於いて $50 \%$ 以上あるも のは84例中74例 $(88.1 \%), 50 \%$ 未満のものは 10 例 $(11.9$ \%) であつ心. 最低 $30 \%$ といらものも 1 例含まれてい る.

(iii) 尿素窒素値

control では20mg/dl以下のものは50例中43例（86.0\%） で 6 例 $(12.0 \%)$ は $20 \mathrm{mg} / \mathrm{dl} よ り 50 \mathrm{mg} / \mathrm{dl}$ 間のもの， 1 例 (2.0\%) に57.0mg/dlのものがあつた. VNC 法の症例で は20mg/dl以下のものは84例中73例 $(86.9 \%), 20 \mathrm{mg} / \mathrm{dl}$ を越 えるものが11例 $(13.1 \%)$ で，手術を行なつたもののう ち最高値は28.6mg/dlであつた。

(iv) その他

腎機能検査として排泄性腎孟撮影法も行なつている 
が，VNC 法を施行した症例では全例に於いて注射 5 分 後造影剂の排泄を認めている.

\section{出血について}

出血量の測定は重量法によつた.

(a) 出血量 (Table 3 , Table 4)

Table 3 は control の症例の平均出血量を示し, Table 4 はVNC 法を施行した症例の平均出血量を示してい る. control の症例の出血量の最大のものは $3,860 \mathrm{cc}$, 最小のるのは150ccで，平均 950ccである. VNC 法によ る症例 (Table 4) では最大出血量 $1,230 \mathrm{cc}$, 最小 $35 \mathrm{cc}$ で, 出血量は年々減少の傾向にあり, 84例の平均出血量 は $378 \mathrm{cc}$ で control の症例の術中出血量 950ccにくらべ

Table 3 Average Bloodloss (Control)

\begin{tabular}{c|c|c}
\hline & $\begin{array}{c}\text { No. of } \\
\text { Cases }\end{array}$ & $\begin{array}{c}\text { Average Bloodloss } \\
\text { (Max.-Min.) c.c. }\end{array}$ \\
\hline 1961 & 15 & $542(1210-172)$ \\
\hline 1962 & 8 & $1064(3860-150)$ \\
\hline 1963 & 5 & $1029(1670-276)$ \\
\hline 1964 & 4 & $922(1870-540)$ \\
\hline 1965 & 9 & $1569(3335-285)$ \\
\hline 1966 & 9 & $878(1900-165)$ \\
\hline Total & 50 & $950(3860-150)$ \\
\hline
\end{tabular}

Table 4 Average Bloodloss (Vesical Neck Closvre)

\begin{tabular}{c|c|c}
\hline & $\begin{array}{c}\text { No. of } \\
\text { Cases }\end{array}$ & $\begin{array}{c}\text { Average Bloodloss } \\
\text { (Max.-Min.) c.c. }\end{array}$ \\
\hline 1967 & 11 & $524(1180-100)$ \\
\hline 1968 & 13 & $513(1230-150)$ \\
\hline 1969 & 28 & $389(1105-50)$ \\
\hline 1970 & 16 & $275(597-84)$ \\
\hline 1971 & 16 & $253(850-35)$ \\
\hline Total & 84 & $378(1230-35)$ \\
\hline
\end{tabular}

1/2以下である.

(b) 手術時間と出血量 (Table 5)

手術時間は control では平均96分（49例平均）であ るが，VNC 法に於いては平均71分と前者に比し短かか つた. 手術時間と出血量の関係をみてみると, control では手術時間が60分以内の症例がなく比較できないが， VNC 法を行なつたものでは 60 分以内に手術を終つた場 合は $250 \mathrm{cc}$ 以下の出血量で, 60分を越えると急に出血量 が増加する.

(c) 摘除標本重量と出血量 (Table 6 )

controlの症例で標本重量と出血量の関係を追究できた
Table 5 Operating Time and Bloodloss

\begin{tabular}{c|c|c|c|c}
\hline $\begin{array}{c}\text { Operating } \\
\text { Time } \\
\text { (min.) }\end{array}$ & \multicolumn{2}{|c|}{ Control } & \multicolumn{2}{c}{$\begin{array}{c}\text { Vesical Neck } \\
\text { Closure }\end{array}$} \\
\cline { 3 - 5 } & $\begin{array}{c}\text { No. of } \\
\text { Cases }\end{array}$ & $\begin{array}{c}\text { Bloodloss } \\
\text { (c.c.) }\end{array}$ & $\begin{array}{c}\text { No. of } \\
\text { Cases }\end{array}$ & $\begin{array}{c}\text { Bloodloss } \\
\text { (c.c.) }\end{array}$ \\
\hline-50 & & & 9 & 245 \\
\hline $51-60$ & & & 21 & 221 \\
\hline $61-70$ & 10 & 416 & 19 & 432 \\
\hline $71-80$ & 6 & 666 & 13 & 519 \\
\hline $81-$ & 33 & 1182 & 22 & 453 \\
\hline
\end{tabular}

Table 6 Weight of Specimen and Bloodloss

\begin{tabular}{c|r|r|r|r}
\hline $\begin{array}{c}\text { Weight of } \\
\text { Specimen } \\
(\mathrm{g})\end{array}$ & \multicolumn{2}{|c|}{ Control } & \multicolumn{2}{c}{$\begin{array}{c}\text { Vesical Neck } \\
\text { Closure }\end{array}$} \\
\cline { 2 - 5 } & $\begin{array}{c}\text { No. of } \\
\text { Cases }\end{array}$ & $\begin{array}{c}\text { Bloodloss } \\
\text { (c.c.) }\end{array}$ & $\begin{array}{c}\text { No. of } \\
\text { Cases }\end{array}$ & $\begin{array}{c}\text { Bloodloss } \\
\text { (c.c.) }\end{array}$ \\
\hline $1-10$ & & & 7 & 460 \\
\hline $11-20$ & 1 & 1536 & 23 & 273 \\
\hline $21-30$ & 5 & 576 & 21 & 397 \\
\hline $31-40$ & 4 & 539 & 12 & 415 \\
\hline $41-$ & 8 & 1157 & 21 & 429 \\
\hline
\end{tabular}

Table 7 Anesthesia and Average Bloodloss

\begin{tabular}{c|c|c|c|c}
\hline \multirow{2}{*}{ Anesthesia } & \multicolumn{2}{|c|}{ Control } & \multicolumn{2}{c}{ Vesical Neck } \\
\cline { 2 - 5 } & $\begin{array}{c}\text { Closure } \\
\text { Cases }\end{array}$ & $\begin{array}{c}\text { Average } \\
\text { Bloodloss } \\
\text { (c.c.) }\end{array}$ & $\begin{array}{c}\text { No. of } \\
\text { Cases }\end{array}$ & $\begin{array}{c}\text { Average } \\
\text { Bloodloss } \\
\text { (c.c.) }\end{array}$ \\
\hline S.C & 50 & 950 & 55 & 414 \\
\hline Ep. & & & 28 & 284 \\
\hline Sp. & & & 1 & 80 \\
\hline
\end{tabular}

ものは18例であつたが, 標本重量最小 $20 \mathrm{~g}$, 最大 $125 \mathrm{~g}$ であつた.VNC 法を行なつた症例では最小 $5 \mathrm{~g}$, 最大 $95 \mathrm{~g}$ であつた. 摘除標本重量 $10 \mathrm{~g}$ 以下の症例は VNC 法 を施行した症例に 7 例あるが，平均出血量は 460 ccであ つた.この $10 \mathrm{~g}$ 以下の 7 例を除くと, 摘除標本重量が大 きければ出血量も増加する傾向にある.

(d) 麻酔法と出血量 (Table 7)

controlの症例は総べて半閉鎖式気管内麻酔を行ない, VNC 法を行なつた症例では半閉鎖式気管内麻醉は55例 (65.5\%), 硬膜外麻酔を行なつたものは28例 (33.3\%), 腰椎麻醉を行なつたものは 1 例 $(1.2 \%)$ であつた. 
Table 8 Macroscopic Hematuria (Control)

\begin{tabular}{c|c|c}
\hline & No. of Cases & $\begin{array}{c}\text { Postoperative } \\
\text { Days of } \\
\text { Hematuria } \\
\text { (Average) }\end{array}$ \\
\hline 1961 & 10 & 4.9 \\
\hline 1962 & 8 & 6.9 \\
\hline 1963 & 5 & 7.4 \\
\hline 1964 & 4 & 11.8 \\
\hline 1965 & 7 & 9.1 \\
\hline 1966 & 6 & 8.7 \\
\hline Total & 40 & 7.6 \\
\hline
\end{tabular}

Table 9 Macroscopic Hematuria (Vesical Neck Closure)

\begin{tabular}{c|c|c}
\hline & No. of Cases & $\begin{array}{c}\text { Postoperative } \\
\text { Days of } \\
\text { Hematuria } \\
\text { (Average) }\end{array}$ \\
\hline 1967 & 11 & 8.3 \\
\hline 1968 & 13 & 5.2 \\
\hline 1969 & 28 & 9.0 \\
\hline 1970 & 16 & 8.9 \\
\hline 1971 & 16 & 7.9 \\
\hline Total & 84 & 8.1 \\
\hline
\end{tabular}

VNC 法を施行した症例で麻酔法別にみてみると，半閉 鎖式気管内麻酔を施行した症例は55例で平均 $414 \mathrm{cc}$ ，硬 膜外麻醉を施行したものは28例で平均 $284 \mathrm{cc} の$ 出血をみ ている.これをみると気管内麻酔を行ならより硬膜外麻 醉を行なつた方が出血は少なくて済むようである。しか して control と VNC 法による出血量を同じ麻酔法即ち 半閉鎖式気管内麻酔法のみで比較してみると，Table 7 にみるように control では50例の平均出血量950cc, VNC 法では55例の平均出血量 414ccであり, control の方法よ り VNC 法の方が出血量が少なく半分以下である.

(e) 血尿持続期間 (Table 8, Table 9)

control の症例中 40 例に追究できたが，肉眼的血尿持 続期間は7.6日であり，VNC 法による症例は8.1日であ つた. 術後の肉眼的血尿持続期間は術式による差はない と思われる。

(a) 術後䫋部狭窄

control の症例では 1 例に頝部㹨窄をみている.VNC 法を施行した症例では 2 例に頝部狭窄を生じた。何れる 膀脂高位切開により膀脱頚部の電気切除を行ない全治し た。

\section{(b) 術後の膀胱結石}

Lower ${ }^{9)}$ は VNC 法の場合膀胼結石が術後に起るかも

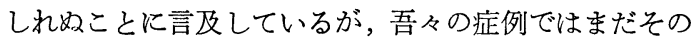
ような例は見当らない。

(c) 死亡症例

control の症例の手術後の死亡は50例中 4 例 $(8.0 \%)$ で，1名は原因不明であるが，他の 3 名は何れも尿毒症 により死亡したものである. この 3 名の術前の尿素窒素

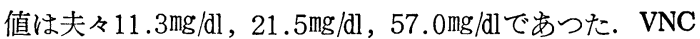
法による手術後入院中の死亡は84例中 4 例（ $4.8 \%$ ) で あつた． 2 例は消化管出血によるものでそのらちの 1 例 は胃潰瘍の既往歴のある患者であつた。 3 例目は手術後 20 日に $50 \%$ メチロンによるショック症状を起し 6 カ月後 に死亡した。 4 例目は不適当な血浆増量剤使用の為之思 われるが，術後14日目に尿毒症より死亡した。

(d) 予後調査について

VNC法を施行した患者に対し最近アンヶートによる予

Table 10 Results of Questionnaire (48 Answers) I Condition of Urination

\begin{tabular}{l|l|r}
\hline $\begin{array}{l}\text { Beginning } \\
\text { of } \\
\text { Urination }\end{array}$ & Good & $44(91.7 \%)$ \\
\cline { 2 - 3 } & Not Improved & $4(8.3 \%)$ \\
\hline $\begin{array}{l}\text { Power of } \\
\text { Urination }\end{array}$ & Good & $40(83.3 \%)$ \\
\cline { 2 - 3 } & Not Improved & $8(16.7 \%)$ \\
\hline $\begin{array}{l}\text { Pain on } \\
\text { Urination }\end{array}$ & No & $44(91.7 \%)$ \\
\cline { 2 - 3 } & Yes & $4(8.3 \%)$ \\
\hline
\end{tabular}

Table 11 Results of Questionnaire (48 Answers) II Frequency of Urination

\begin{tabular}{c|c|c}
\hline Frequency & Daytime & Night \\
\hline 0 & & 3 \\
\hline 1 & & 14 \\
\hline 2 & & 14 \\
\hline 3 & & 12 \\
\hline 4 & 2 & 2 \\
\hline 5 & 8 & 1 \\
\hline 6 & 11 & 2 \\
\hline 7 & 8 & \\
\hline 8 & 11 & \\
\hline 9 & 4 & \\
\hline 10 & & \\
\hline 11 & 3 & \\
\hline
\end{tabular}


Table 12 Results of Questionnaire (48 Answers) III Miscellaneous

\begin{tabular}{l|c}
\hline Recovered & $31(64.6 \%)$ \\
\hline Not Improved & $9(18.8 \%)$ \\
\hline Declined & $8(16.7 \%)$ \\
\hline
\end{tabular}

後調査を行つた. 84名中返事のあつたのは48名で，排尿 状態その他の集計の結果を Table 10に，排尿回数関す る集計の結果を Table 11に示した．排尿状態についての 集計結果は注満足すべきものであつたが，排尿回数に ついては昼間はよいとしても，夜間 3 回以上起きる症例 が17例（35.4\%）あり，6回起きなければならない症例 が 2 例もあつた. 現在その原因をしらべ，症状の改善を はかりつつある。

\section{考 按}

前立腺摘除術の歴史を顧みてみると, 術中・術後の出 血をいかに巧く処理して患者の術後経過を良好にするか といら工夫の歷史とも言光る．前立腺腺腫を摘除したあ との処理方法を Macalister ${ }^{11)}$ は

1. hot irrigations

2. packing

3. inflatable bags

4. hemostatic gauze

5. irrigations (continuous, intermittent)

6. direct control of bleeding vessels

7. hypotensive anesthesia

の 7 つ要約している. 而して露出した出血中の血管を 直接 control できればそれが最も望ましいことは論を俟 たない，又腺腫を摘除したあと膀胱内に血液凝塊がで き，留置したカテーテルから尿の排出に㷴々円滑さを欠 き患者が苦しむことがある.これについて1927年Lower9 は腺腫を摘除したあとの腺床と，膀胱を遮断してきれい， な尿流を確保し，一方前立腺腺床の出血は凝血による 自然止血をまつ方法を発表し，その後このような考觉に 沿つた手術法について諸種 ${ }^{2338)(12)}$ の報告がある. 我が国 では落合 ${ }^{15)}$, 水本 ${ }^{13) 14)}$ ら, 赤坂 ${ }^{11}$ の報告がある. 吾々の 行なつた VNC 法（吾々は横に縫合 (Fig.1) している が，Lower は縦に縫合(Fig. 2)した) による症例が80例 を越えたので，この方法を検討する為に緾めてみたわけ であるが，出血量の測定に重量法を用いたので必ずしも 正確ではないという憾みはあるが，大方の目安にはなろ らかと思い， control として吾々の行なつていた Harris
Fig. 2 Vesical Neck Closure(Lower's method)

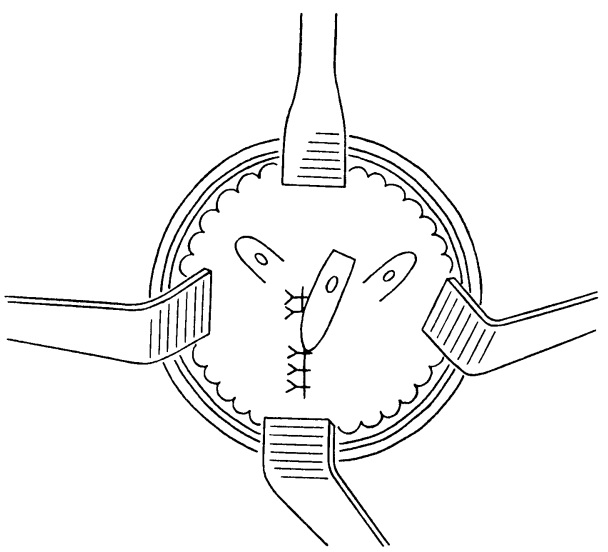

法の変法を施行した症例を用い結果を Table 3, Table 4 に示した. 前にみたよらに VNC 法が control に比し出 血は少ないようである. 又麻酔法との関係を Table 7 に 示したが，気管内麻酔より硬膜外麻酔の方が出血量は少 なかつた。

この前立腺腺床と膀胧を遮断するために膀胱䅡部を縫 合するVNC 法で当然問題になるのは術後に膀脱頝部の 狭窄が起らないかといらことであろらが，落合 ${ }^{15)}$ ，水 本 ${ }^{13) 14)}$ らもこれにふれて狭窄は起らかなつたといつてい る. 吾々の症例で control と比較した場合差はなかつた し, 狭窄の問題は手術法よりも膀脱頙部の結締織や筋肉 の個人差によるものと思われる. ただ何れの場合でも膀 胱頝部の狭窄は避けるべきであるので, 腺腫摘除後の腺 床からの出血は24時間後にはほぼとまることに鑑み, 膀 胱䅡部の環状切開は膀脱之前立腺の境上り許す限り膀脂 側に切り込み，系は「000」の plain の catgut を使用 するようにしてなるべく早くゆるむことを期待してい る. 又 Lower $^{9)}$ は catgut を核として膀胱結石のできる のを心配しているが，吾々の症例では現在迄に結石ので きたものはなかつた。

結 語

1. 吾々の行なつている VNC 法は, 出血が少なく優 れた方法であると思われる.

2. 気管内麻酔下の手術時出血之硬膜外麻酔下のそれ とを比較すると, 硬膜外麻酔による手術の方が出血は少 なかつた。

3. 術後に起る膀睄頝部の狭窄は，手術法よりも多分 に個人差によるものと思われるが，尚，一層工夫を行な いつつある。 
4. 死亡症例に VNC 法と直接関係があつて死亡した と思われる症例はなかつた。

\section{主要文献}

1) 赤坂 裕 : 泌尿器科手術, 281頁, 1966, 金原 出版株式会社, 東京.

2) Cohen, S.P., Kopilnick, M.D. and Robbins, M.A.: J. Urol., 102, 720, 1969.

3) de la Peña, A. and Alcina, E.: J. Urol., 88, 86, 1962.

4) Flocks, R.H.: J. Urol., 37, 524, 1937.

5) Harris, S.H.: Surg., Gynec. \& Obst., 45, 692, 1927.
6) Harris, S.H.: Brit. J. Urol., 1, 285, 1929.

7) 畠 亮: 手術, 24, 957,1970.

8) Krahn, H., Morales, P. and Hotchkiss, R.: J. Urol., 96, 83, 1966.

9) Lower, W.E.: J.A.M.A., 89, 749, 1927.

10) 林 来耀: 泌尿器科紀要, $7,481,1961$.

11) Macalister, C.L.O.: J. Urol., 87, 930, 1962.

12) Maluf, N.S.R.: J. Urol., 82, 531, 1959.

13) 水本龍助: 手術, 17, 560, 1963.

14) 水本龍助, 三宅則保, 身吉隆雄, 並河広二, 西 村邦康, 柴田 昭, 福地 晋: 手術, 18, 203, 1964.

15）落合京一郎：日泌尿会誌, 53, 347,1962. （1972年10月 2 日受付, 特別掲載） 